\title{
An Analytical View of Selected Commercialized Recordings of Ghanaian Art Music Compositions
}

\author{
George Asabre Maclean* \\ Department of Music Education, University of Education, Winneba
}

*Corresponding Author: George Asabre Maclean, Department of Music Education, University of Education, Winneba, Ghana

\begin{abstract}
The paper takes a scrutiny of how selected Ghanaian art compositions, specifically choral works, have been wrongly performed and recorded for commercial purposes by renowned choral groups and gospel artistes in Ghana. The selected recorded works evince errors heard in some passages of the compositions (as scored); in terms of wrong pitches, rhythm interpretation and alteration of some of the texts. Using exploratory, 10 audio-recorded Akan choral compositions were purposively selected from compact discs of renowned choral groups and gospel artistes and analyzed. It was revealed that some commercially recorded choral pieces were done with errors pertaining to particular passages in the original scores. It was concluded that in spite of the seriousness attached to the learning and recording of such pieces, it is not every recorded art musical composition that gives a vivid representation of what exists on the score. It is therefore recommended that art music composers record their works first hand or see to the correct representation by other performers, especially if the intent is a commercialization of the recording.
\end{abstract}

Keywords: Art Music, Choral Music, Commercialization, Akan, Ghana

\section{INTRODUCTION}

A major goal of teaching a composed art choral music is to ensure the accurate interpretation of the music for the performers to sing exactly as it has been written on the score by the composers. When a particular choral music is taught differently, either in harmony, rhythm, melodic alteration, textual modifications, other than what exists on the score, it becomes an error. The musical score itself is "inaudible and abstract" but when it is "particularized and concretized" (Ferguson, 1983, p.17) in the form of performance or recorded in any form, most aficionados of choral music, especially in a cultural setting such as Ghana where choral music permeates, get access and learn them. In view of this, it becomes worrying when a piece of choral art music is recorded with portions of the original script changed.

The art musical composition in Ghana is dominated by choral music which are used by church choirs and other choral groups at social functions. As a result of the growth of this medium of composition, various non-denominational youth choirs have sprung up with some of them performing and audiorecording such pieces for commercial purposes. Sometimes, the recorded streams are made readily available through services such as YouTube, Spotify and Apple Music, where the masses download and learn them. Some of these choirs are the Winneba Youth Choir, Accra Youth choir, African Youth Choir, The Harmonious Chorale Ghana, Tema Youth Choir, Okyeman Youth Choir, to mention a few. Similarly, other renowned Gospel artistes also audio-record such existing pieces, especially, when the tunes become popular. In recent times, there have been attempts of philosophical studies in choral music composition and performance in Ghana which have focused on wellbeing (Acquah 2016), choral performances of youth choirs (Amuah \& Acquah, 2013) and analytical studies (Amuah \& Acquah, 2014). However, in the aspect of studies on recording of such choral works, there has not been much research that could help to improve and maintain the originality of the works.

Indeed, many of the composers do not either record their songs themselves or take steps to own copyright of their works. It is rather these renowned choral groups and the gospel artistes who finally put them on compact discs (CDs) and other possible social media and get their CDs registered. Unfortunately, these renowned choral groups and gospel artistes who perform and record the songs for commercial purposes at times do the recording with errors in terms of changes in melodic lines, 
rhythm, harmony and the texts of the pieces. This consequently presents a disparity between what exists on score and what is heard in the audio-recording. As much as these works are written for choral groups and the churches, the owners of such choral compositions do not make much effort to record their works for the public. I believe that Ghanaian choral composers tend to think that it is enough for church choirs and notable performers to render their works once it is in the public domain.

This paper therefore addresses this imbalance and extends the body of research that investigates performance error detection in the context of various textural factors through exploration and analysis. It focuses specifically on identification of such recorded songs on CDs and compares with their scored counterparts. It highlights the enormity of errors that some performers make in their performance and recording of choral music compositions meant for public consumption. This will not only sensitize the listening public and singers but bring to the attention of composers the need to get their works recorded and publicized. My conviction is not to surprise or offend the leading members of such choral and artiste groups but to educate patrons of choral music on the correct and original composition of the selected works. It is envisaged that choral groups and artistes who perform and record such compositions will be educated on the need to strictly perform works as scored by the owners.

\section{REVIEW OF RELATED LITERATURE}

Sound recording is an electrical, mechanical, electronic, or digital inscription and re-creation of sound waves, such as spoken voice, singing, instrumental music, or sound effects (Maxfield \& Harrison, 1926). Recording and commercializing an art music composition, either instrumental or vocal, by way of audio or video, affords audience and patrons of such works the opportunity to learn the songs along. Indeed, most of the patrons may not have the capability of interpreting the notation or even reading the text if the score is available. Thus, recording a composer's work, commercializing and eventually getting it broadcasted must be done with the requisite fastidiousness.

Relatively little information of an empirically derived and specific nature of analytical studies on choral musical compositions and performances in Ghana which provide attention to composers and performers is available. Acquah, Amuah, Annan and Tsemafo-Arthur (2015) for instance talked about how composers or songwriters sometimes fail to pay attention to the semantic synchronization of the text chosen for their choral compositions. It became clear from their study that some of the Akan choral compositions have been identified to have problems with the meaning of the text in terms of sentence cohesion, wrong usages of song personas and the context in which the narrative of the song is put. It was important that these errors were detected to draw composers' attention to such anomalies in art music compositions.

Randel (1978) gave a close explanation of art music with the definition of art song, by drawing a distinction between it and folksong, as a song of serious artistic intent written by a trained composer. The inclusion of the words "serious artistic intent" and the distinction from a folksong in Randel's definition clearly testifies that art music is punctiliously designed and therefore expected to be replicated as indicated in the score. More insidiously, at least from the perspective of the musicians in the choral music fraternity, is whether such songs, which have been impeccably taught and learnt, will not be adulterated or affected by the anomalies in the performances of their choral groups, who are also patrons of those audio-recordings. Describing a piece of work as an art suggests that the work involves careful planning and design and also requires some skill to execute or carry out. Thus, describing a musical piece as art gives the implication that the composer and the work meet the description given. The task for teachers and directors is therefore to quickly correct errors that occur, before inaccurate or incorrect aspects of performed or recorded pieces become resistant to change. Errors occur naturally in the learning process, and how teachers deal with inevitable errors in the choir performance is one of the fundamental components of teaching expertise (Sheldon, 1998).

As already stated, choral music permeates the Ghanaian culture so much that any wrongly recorded piece of music spreads easily. Amuah gave a survey of Art Choral music in Ghana and stated:

In situations concerning the performances of choral music in Ghana, it has been the norm to celebrate an event or an anniversary of an organization with a special composed musical piece. Most churches, schools and industries would often hire a 
composer to write for the celebration and other events in a similar style. Anniversary programmes equally call for the performance of choral music. (Amuah, 2013, p. 246).

Amuah mentioned some identifiable groups such as Educational institutions, Urban factories and the Industrial Choirs, Radio and Television stations, The National Symphony Orchestra, Salt and Light Ministries, Youth and Junior Choirs, and church choirs that have been involved in spreading art choral music. Everyone loves either to listen to or sing Choral music in Ghana. Like Smith (1989) stated:

Singing provides a sense of community and belonging and that Music is a component of cultural identity, and singing is the most basic musical expression. [...] singing provides lifelong opportunities for musical experience and self-expression with minimal expense. Beyond that, singing like all music, can be a source of joy, comfort, and emotional sensation. (p.27)

Indeed, it is as a result of this that recordings of such pieces need to be done without errors or modifications when the song had especially been in the public domain already.

Discourse on tone errors does not apply to music alone but also in language. In language production, speech errors often involve related sounds or meanings, which may arise from the computation of similar components (Garrett, 1975). Fry (1969) is of the view that "theories of language production posit the assembly of higher order (earlier) components (such as a semantic representation) before lower order (later) components (such as a phonological representation". This is corroborated by Palmer and Van de Sande (2006) who relate the assertion to music and state:

An internal buffer stores the earlier planned components, which are retrieved during planning of the later components. Speech errors thus may involve similar elements because similar units are caused to co-occur in the buffer. Music production errors may likewise provide insights about the musical elements that contribute to, or compete in, the planning of a particular sequence of events. (Palmer and Van de Sande, 2006, p.459)

This assertion remains the fact that the errors emanating from the performance or the recording may reflect some correspondence between the composer's specification of musical structure and the performer's conceptual representation, giving the performer some kind of artistic license, however, in art music, it is important that the particularized and concretized reflect the emotions and communication of musical structure as exactly the composer put on the score. Smith (1989) explains the social relationship between the listener and the composer and state:

Upon hearing the first notes of the musical work, the listener immerses himself in the ongoing flux of the articulated musical events as they occur. He grasps the musical meaning by "living in" and "re-producing" the step by step flux of the articulated musical events in inner time. This polythetically constituted musical work, itself existing in inner time, however, is none other than the musical meaning originally intended by the composer and communicated by means of a series of events in the world. (Smith, 1989, p.84)

When the listener picks it as they hear it from the audio-recording, they live with it and becomes difficult to correct. Like Smith (ibid, 82) stated, "It is left more or less to the performer to interpret the prescriptions offered through the musical notation so as to achieve the most effective communication of the musical work".

\section{Method ANd PROCESS}

The main concern of this study was to explore and analyse such audio recorded Akan choral pieces which have some disparities with the original script by the composer. In view of that, exploratory research design was used to gather the data. Exploratory research design is referred to as gathering information in an informal and unstructured manner. The design is proper when the researcher knows small about the opportunity or issue (Burns \& Bush, 2006). With limited study on the problem, I had to use exploratory research to crystallize the problem in order to generate more rigorous further 
research within the framework of art music compositions and their recordings in any form. 6 audio recordings from two popular youth choirs and 3 renowned gospel musicians were collected and critically listened to the audio-recordings over and over again and compared with their respective scores which I had gathered as part of my repertoire, as a choir director. Using the purposive sampling technique, 10 songs in the Akan language were selected. In purposive sampling, the researcher decides what needs to be known and sets out to select documents that will provide the necessary information for the study (Bernard, 2002; Lewis \& Sheppard, 2006).

The table below details the pieces which were purposively selected from the audio recordings.

Table1. Selected songs from the audio-recordings

\begin{tabular}{|c|c|c|c|c|}
\hline $\mathbf{S} / \mathbf{N}$ & Title of track & Composer & Recorded by & Album Title \\
\hline 1 & $\begin{array}{l}\text { Yen ara asase ni } \\
\text { (This is our own land) }\end{array}$ & Ephraim Amu & Winneba Youth Choir & To God and Country \\
\hline 2 & $\begin{array}{l}\text { Menyew' nam a, munnsuro hwee } \\
\text { (Walking with you, I fear no ill) }\end{array}$ & Newlove Annan & Winneba Youth Choir & $\begin{array}{l}\text { Praise and Worship } \\
\text { Vol. } 1\end{array}$ \\
\hline 3 & $\begin{array}{l}\text { okyeso Nyame } \\
(\text { Benevolent God) }\end{array}$ & Newlove Annan & Winneba Youth Choir & $\begin{array}{l}\text { Praise and Worship } \\
\text { Vol. } 1\end{array}$ \\
\hline 4 & $\begin{array}{l}\text { Daa mbosom wo } \\
\text { (I will forever worship you) }\end{array}$ & J. Y. Sekyi-Baidoo & Winneba Youth Choir & $\begin{array}{l}\text { Praise and Worship } \\
\text { Vol. } 1\end{array}$ \\
\hline 5 & $\begin{array}{l}\text { Afrenhyiapa } \\
\text { (Christmas greetings) }\end{array}$ & H. B. Sam & Winneba Youth Choir & $\begin{array}{l}\text { Christmas with Winneba } \\
\text { Youth Choir }\end{array}$ \\
\hline 6 & $\begin{array}{l}\text { M'akokycm Nyame } \\
(\text { God, } \text { my shield })\end{array}$ & Harvey Essilfie & Winneba Youth Choir & $\begin{array}{l}\text { Hymns and Anthems } \\
\text { Vol. } 1\end{array}$ \\
\hline 7 & David & Kow Arthur & Tema Youth Choir & Adom \\
\hline 8 & $\begin{array}{l}\text { Ensuro, Yesu ka wo ho(Fear not! } \\
\text { Jesus is with you) }\end{array}$ & Osei Boateng & Cecilia Marfo & Time of worship \\
\hline 9 & $\begin{array}{l}\text { Aseda y } \varepsilon \text { wodze } \\
(\text { Appreciation is yours) }\end{array}$ & J. Y. Sekyi-Baidoo & Joe Beecham & \begin{tabular}{|l} 
The Best of Pastor Joe \\
Beecham
\end{tabular} \\
\hline 10 & $\begin{array}{l}\text { Nyame dzi hen } \\
(\text { God reigns) }\end{array}$ & J. Y. Sekyi-Baidoo & Oware Junior & Worship Medley \\
\hline
\end{tabular}

Errors detected in the audio-recordings of the songs as against the scores were identified, classified and analysed.

\section{ANALYSIS AND RESUltS}

In analyzing the pieces, 5 of the songs representing $50 \%$ were chosen through the systematic sampling technique. Systematic sampling is a type of probability sampling method in which sample members from a larger population or units are selected according to a random starting point and a fixed periodic interval (Gundersen, Jensen, Kieu \& Nielson, 1999). In doing this, the first song in the auxiliary data, table 1 , with cell number 1 was chosen at random while all songs corresponding to every odd cell number was also chosen. Finally, songs with cell numbers 1, 3, 5, 7 and 9 were chosen and analysed. The table shows the titles of the chosen songs.

Table2. Selected songs for analysis

\begin{tabular}{|l|l|l|l|}
\hline S/N & \multicolumn{1}{|c|}{ Title } & \multicolumn{1}{|c|}{ Composer } & \multicolumn{1}{|c|}{ Recorded by } \\
\hline 1 & Yen ara asase ni (This is our own land) & Ephraim Amu & Winneba Youth Choir \\
\hline 3 & okyeso Nyame (Benevolent God) & Newlove Annan & Winneba Youth Choir \\
\hline 5 & Afrenhyiapa (Christmas greetings) & H. B. Sam & Winneba Youth Choir \\
\hline 7 & Ebenezer & Kow Arthur & Tema Youth Choir \\
\hline 9 & Aseda ye wodze (Appreciation is yours) & J. Y. Sekyi-Baidoo & Joe Beecham \\
\hline
\end{tabular}

The songs chosen were representative as the selection fell on 3 songs out of 6 from Winneba Youth Choir, 1 from Tema Youth choir and 1 from Joe Beecham (representing the three gospel musicians).

The songs were put into three analytical themes of errors under three main elements of music. These errors had to do with the wrong pitching of notes (WPN) which, in effect, affected the melodic lines and chords used by the composer in such passages, wrong note value interpretation (NVI), which 
affected the rhythms used by the composer in certain passages of the score and text alteration (TA) which changed, entirely, portions of the text of the original songs. The analysis centred on musical illustrations of what exists in the scores by the composers, viz-a-viz what the performers sang in the audio-recordings.

\begin{tabular}{|l|l|l|}
\hline & Title of Song & Analytical Theme \\
\hline 1 & Yen ara asase ni (This is our own land) & WPN \\
\hline 2 & okyeso Nyame (Benevolent God) & WPN and NVI \\
\hline 3 & Afrenhyiapa (Christmas greetings) & NVI \\
\hline 4 & David & TA \\
\hline 5 & Aseda ye wodze (Appreciation is yours) & TA \\
\hline
\end{tabular}

\subsection{Wrong Pitching of Notes}

The first song identified here is Ephraim Amu's "YenAraAsaase Ni"(This is our own land), a very popular patriotic song in Ghana. The composition, as performed by the Ghanaian populace, most of the time, has a couple of pitches wrongly produced in its rendition. Composed in the key of $F$ major, the work has, in its sixth phrase, two E flat pitches to be sung at a point as illustrated below.

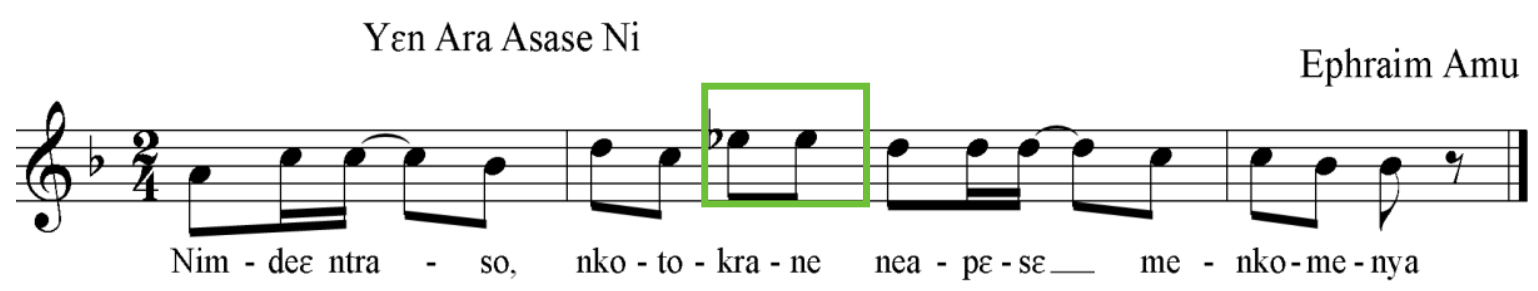

Excerpt1. The correct pitches used in Amu's "Yen Ara Asaase Ni"

However, the passage is most often sung with the first $\mathrm{E}$ flat pitch produced as $\mathrm{D}$ and this error was reiterated by the Winneba Youth Choir (WYC) in their album titled "To God and Country".

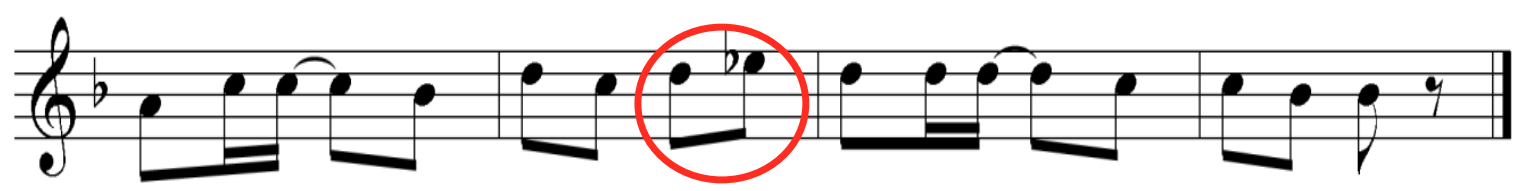

Excerpt2. Wrong rendition in the recording

Also, in the last phrase of the same composition, Amu has a pitch at $\mathrm{C}$ but often produced by singers as B flat. The error was corroborated by the choir in the same rendition of the anthem Excerpts 3 and 4 , respectively, show the correct composition and the wrong rendition of the passage in point.

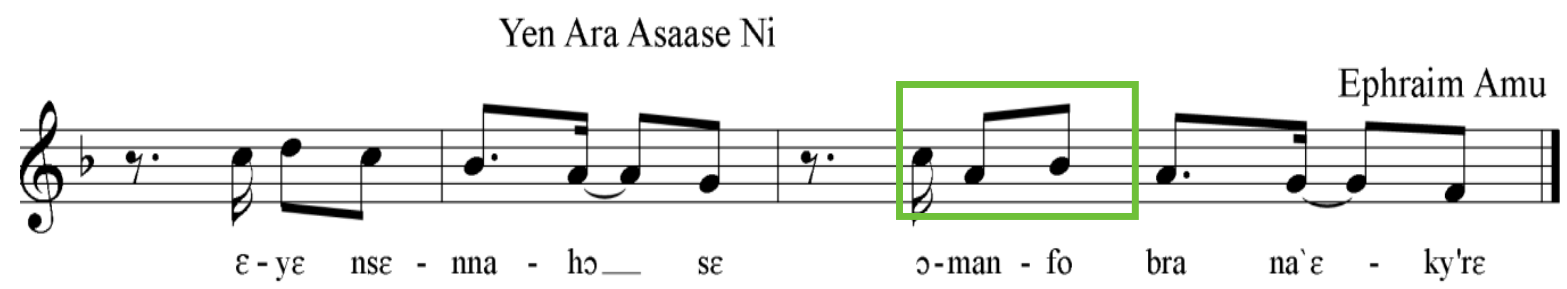

Excerpt3. Concluding passage of the anthem

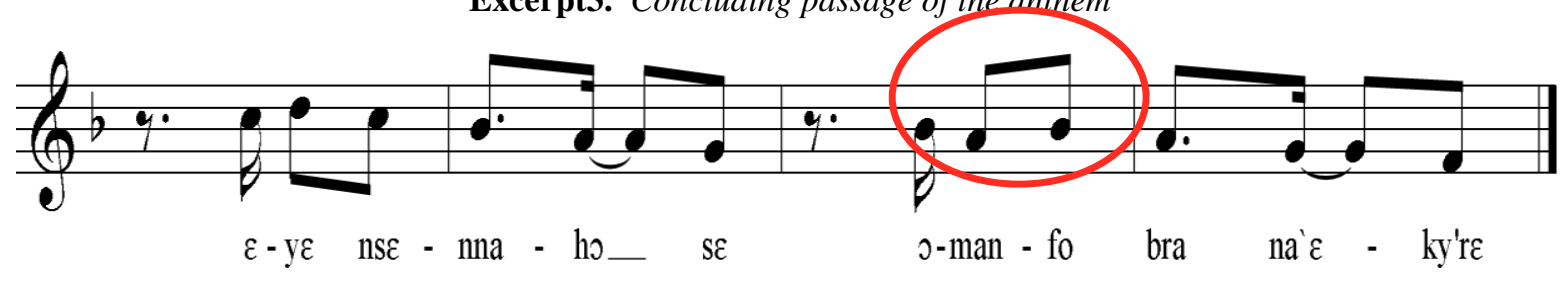

Excerpt4. Wrong rendition of passage

The second work in the discussion, which also borders on wrong pitching of notes is Dkyeso Nyame (Benevolent God) by Newlove Annan and recorded by the Winneba Youth Choir, Ghana. The first 
flaw, in this case, comes with the pitches juxtaposing the text, twer No, twer No, na Nyame beye ama $w^{\prime}$ (lean on Him, lean on Him, and God will do it for you). The error is identified, both, in the choral performance and in the male solo of the recording by the choir. Excerpt 5 shows how the passage was composed and the error in the recording is illustrated below.

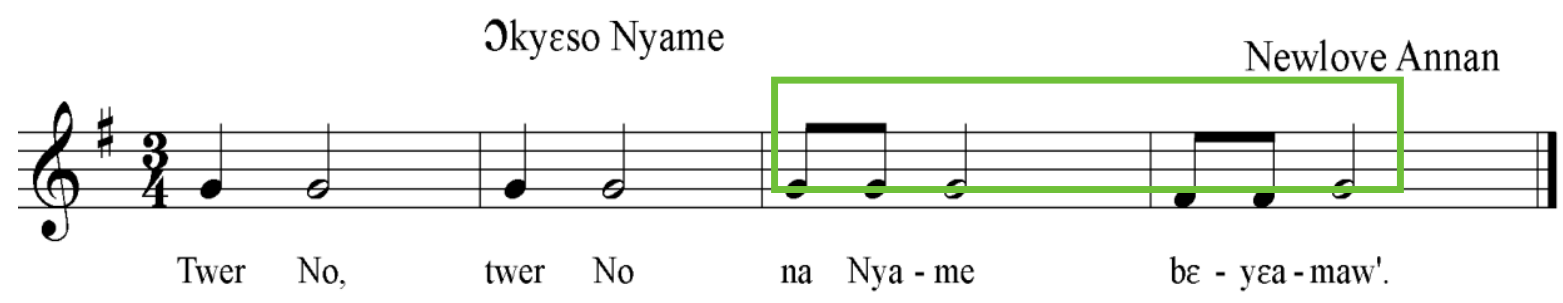

Excerpt5. Composer's idea as notated

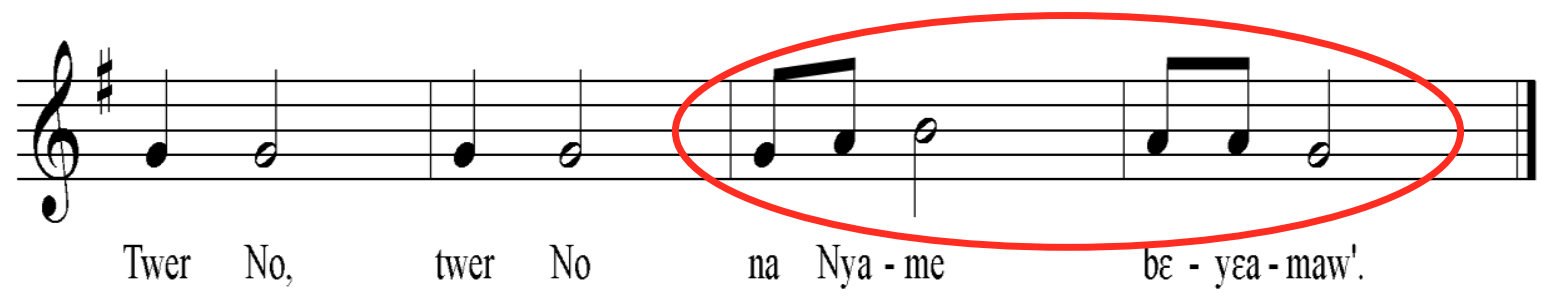

Excerpt6. Wrong presentation of composer's idea

\subsection{Note Value Interpretation}

Notes, in music, are used to represent the duration and pitches of musical sounds (Benward, 2014). They represent how long or short a pitch or sound is to be made in a musical work. In the second flaw discussed under Wrong pitching in the same recording, the choir also wrongly interpreted a set of notes written for the Alto part by performing a quaver beamed with two semiquavers as a triplet. Excerpts 7 and 8 show the correct and wrong rhythms respectively.

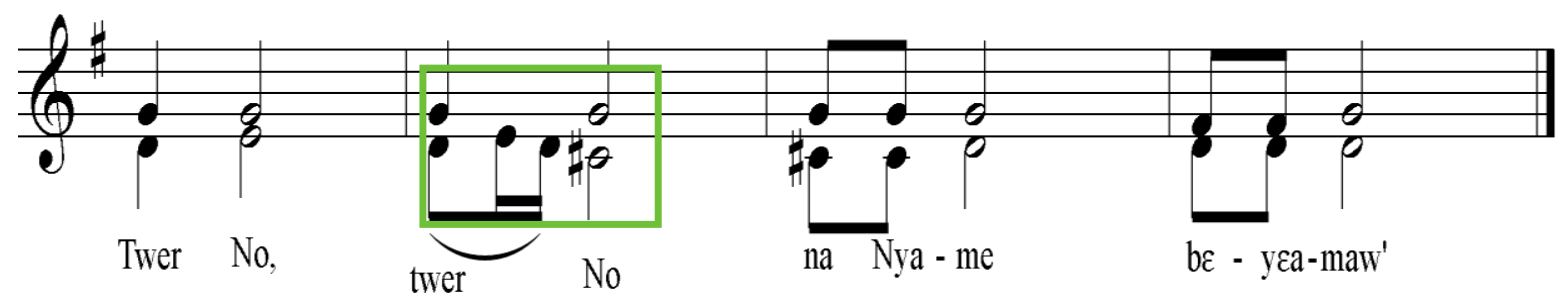

Excerpt7. Correct rhythm by composer

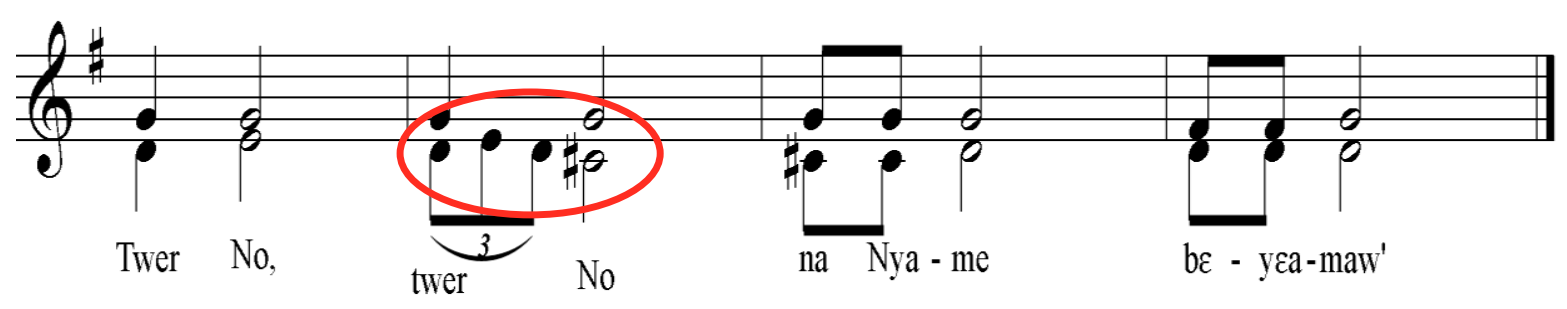

Excerpt8. Wrong interpretation in recording

Also, one very popular Ghanaian song sung during the Yuletide, Afehyia Pa which was composed by H. B. Sam has over time, suffered a wrong rendition due to the wrong interpretation of notes towards the end of the song. The duration given to the word, bio (again) is often shortened and compensated with another set of wrong notes which do not even exist in the song. With the aim of recording this song as part of its Christmas songs album, the Winneba Youth Choir could have used the music, as written by the composer, to help correct the listening and singing masses as to how the song is supposed to be sung. Unfortunately, this was not done and the same flaw was done in the commercialized album. See Excerpts 9 and 10. 


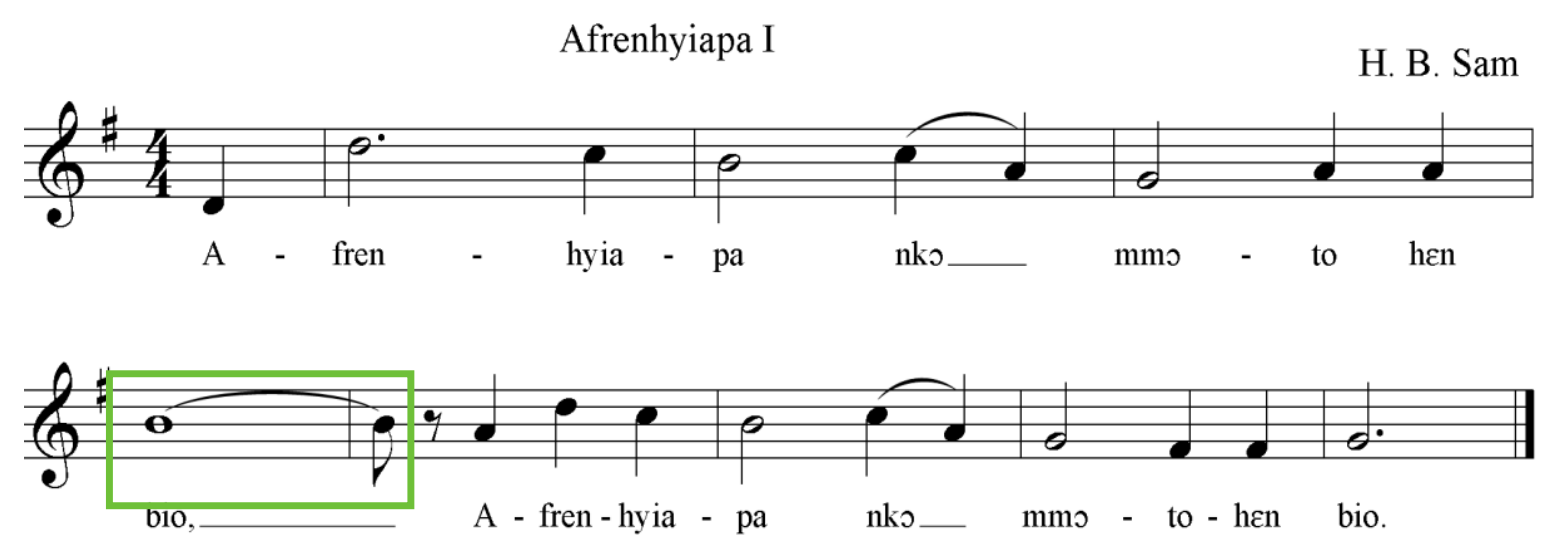

Excerpt9. Sound duration specified in composition

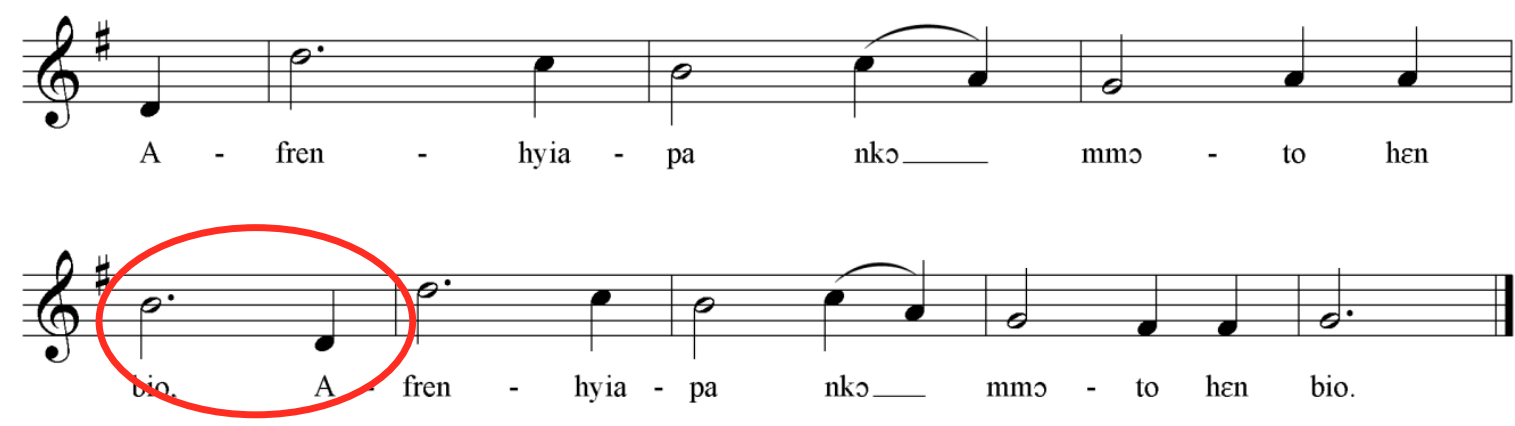

Excerpt10. Passage as presented in recording

\subsection{Text Alteration}

The first observation made in this regard is in the recording of Samuel Kow Arthur's tune "David", popularly known among singers as Yebotow Ebenezer [We shall sing Ebenezer], by the Tema Youth Choir, Ghana, who substantiated an error with the text in the last line of the song's refrain. The particular line, in this context, which is supposed to read and be sung as Yebotow Ebenezer, yeatonton Ewuradze (We shall sing Ebenezer, and shall extol the Lord) has, over time, been wrongly sung by the masses as Kae dza Nyame aye ama wo, na fa ndaase ma No (Remember what the Lord has done for you, and give thanks to Him).The passages are illustrated in excerpts 11 and 12 .

David

Samuel Kow Arthur

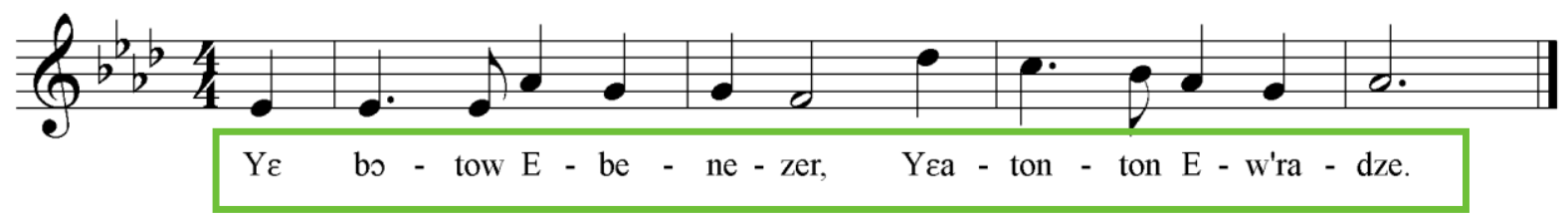

Excerpt11. Correct text as used by composer

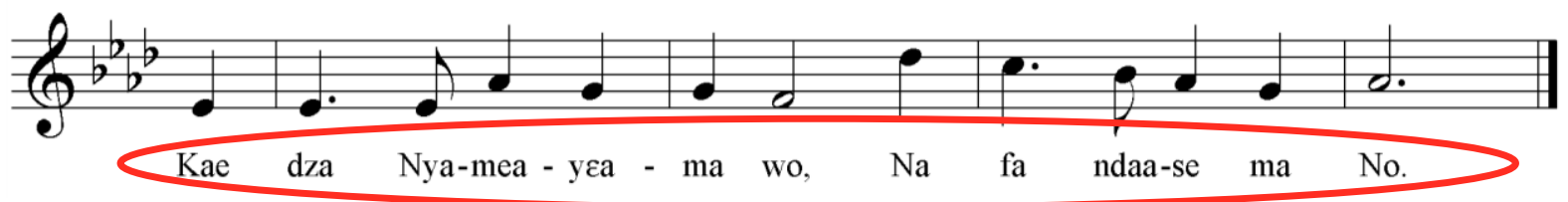

Excerpt12. Wrong text used by singers

In another instance, Aseda $Y \varepsilon$ Wodze by Yaw Sekyi-Baidoo which was sung and recorded solo by Pastor Joe Beecham, the artiste sang the melody but inserted some lyrics which are supposed to be sung by Alto at some point and another written for Alto and Tenor when the work is performed by a choir (see Excerpt 13). Musically envisaging that the insertion of such words, while using the right pitches assigned by the composer, could not fit into the melody being performed, pitches were created for those lyrics so as to fit into the melody. These insertions are found in the first phrase of the song 
Aseda nyina ye Wodze (mo Wura) which is followed by Jesus, me botantim (Nyame)"as shown in Excerpt 14.

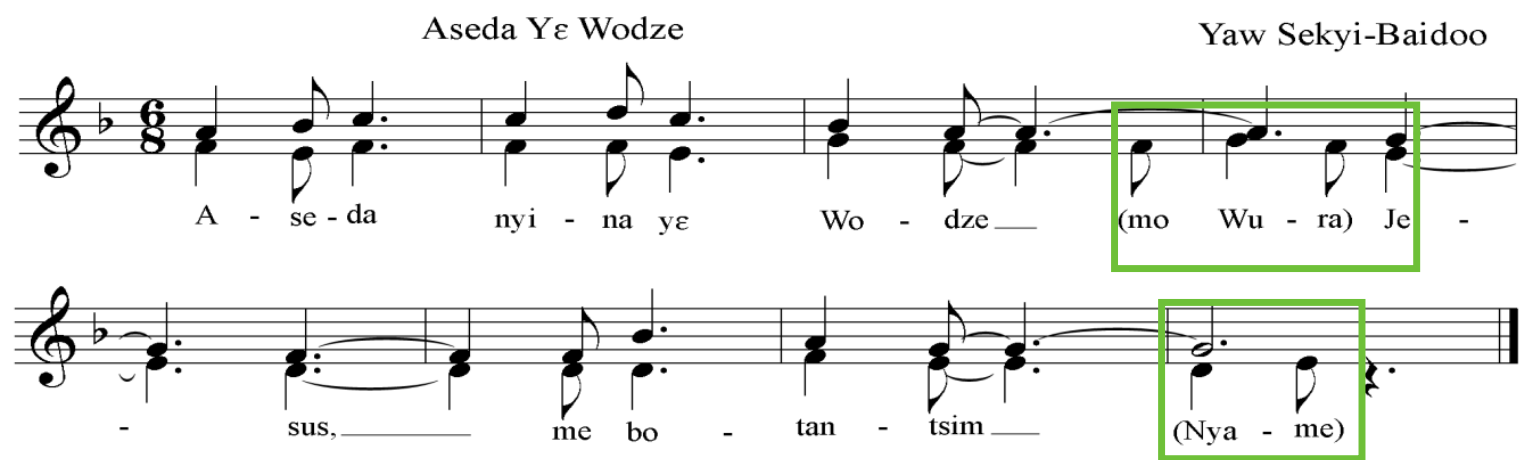

Excerpt13. Beginning passage for Soprano snd Alto parts

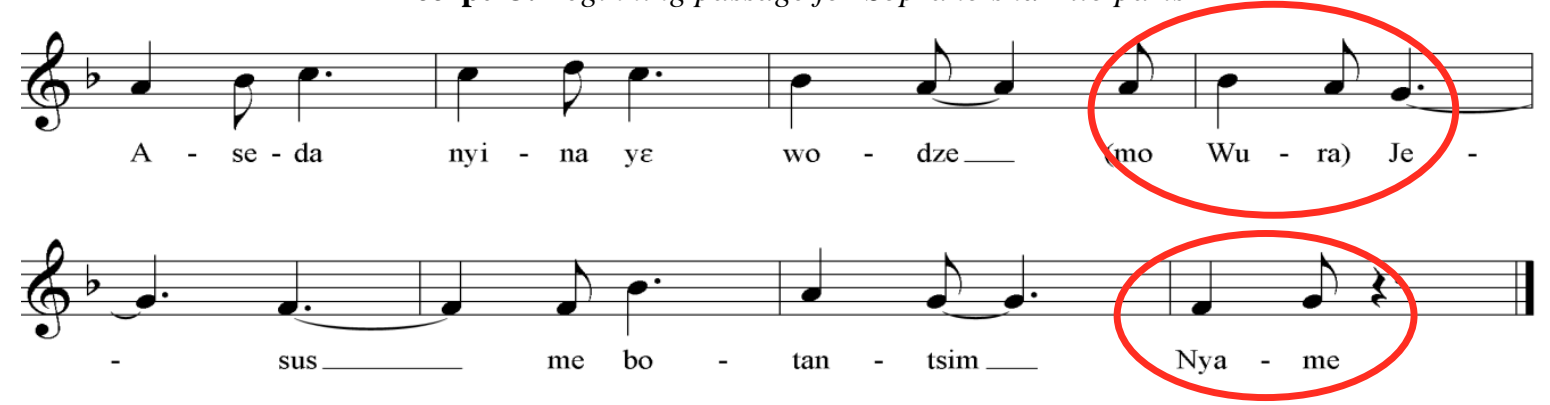

Excerpt14. Wrong presentation of melody in recording

An even more serious error in this recording which has, to date, made the listening public think that that is the original text in the composition is the line where the composer wrote Onyame, dza Aye dosso, W'adom tsim ho daa nyinaa (God, what You have done are many; Your grace endures for ever) [see excerpt 17). In contrast, the text was substituted entirely with Onyame, dza Ayc dosso, W'adom ntsi na yctse ase [God, what You have done are many; by Your grace that we are alive) [see excerpt 18).
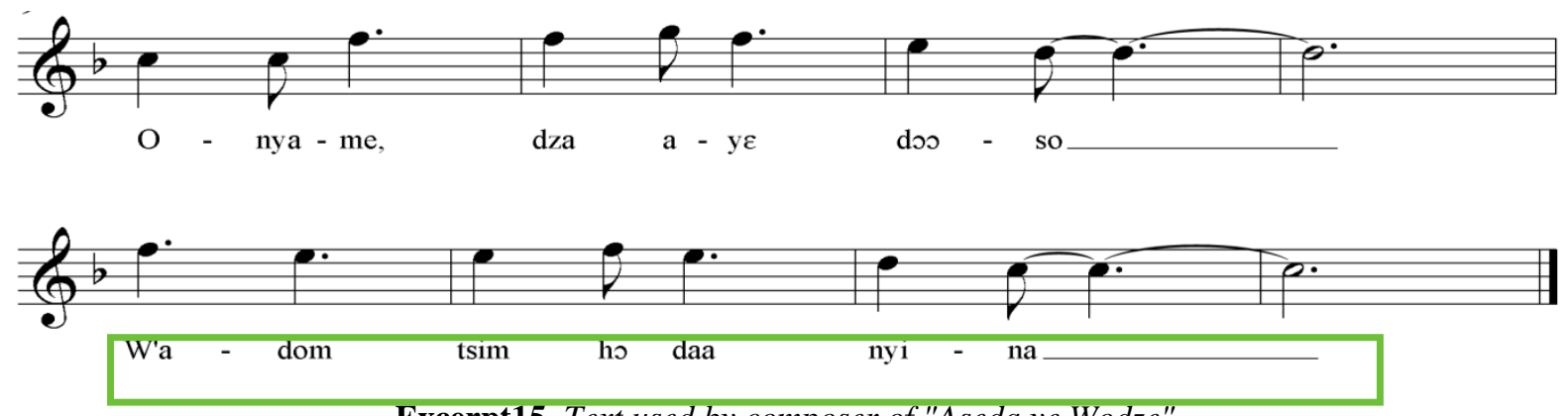

Excerpt15. Text used by composer of "Aseda ye Wodze"

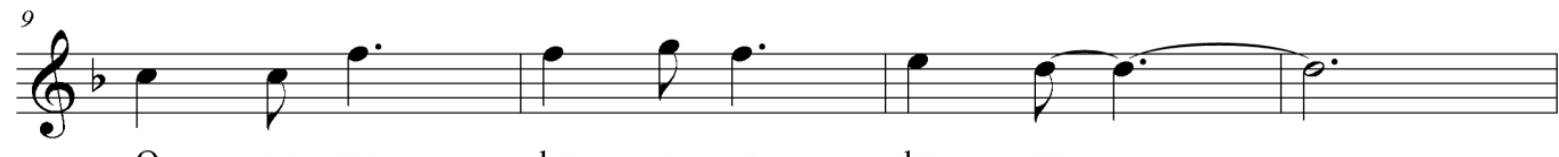

$\mathrm{O}-\mathrm{nya}-\mathrm{me}, \quad \mathrm{dza} \quad \mathrm{a}-\mathrm{y} \varepsilon \quad$ doo - so

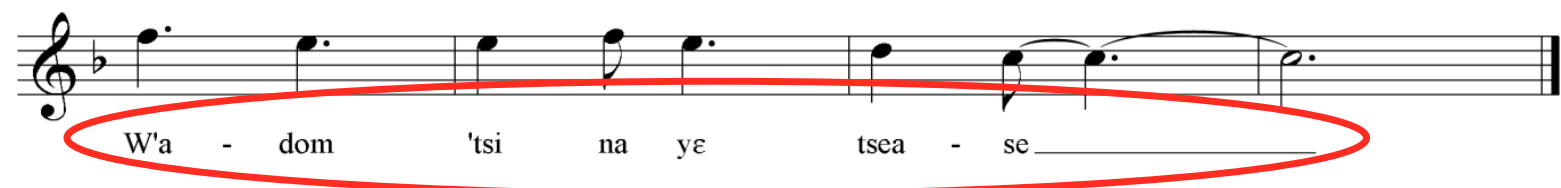

Excerpt16. Text used by artiste in the recording

\section{CONCLUSION AND RECOMMENDATION}

The study conducted was mainly through a critical examination of Akan choral songs which have been wrongly recorded for commercial purpose. In some cases, the songs with errors had been heard 
on airwaves before the score of the song was encountered later by the researcher while in other instances, the researcher was privy to the scores before hearing the audio-recording. This paper has contributed to the discussion on errors in audio-recordings of choral music in Ghana. It has confirmed that pitch errors, wrong interpretation of notes as well as textual alterations exist in some Akan choral art music compositions which have been recorded in Ghana. Indeed, the originality of the songs as they exist on the scores is critical in the mind of the composer; therefore, changing portions of it will mean destroying the imaginative and constructive thoughts of the composer. By commercializing the recording, the wrong lyrics are caught up with singing groups and individuals of choral music, most of who sing the lines as recorded. Therefore recording a piece of work, in any form, requires a great deal of verification in order to present to the listening public, an authentic material which can also serve educational and reference purposes. It is important that we examine the nature of the various social relationships which exist between the composer, performer, and listener in this direction (Smith, 1989, p.83)

My own experiences as a director, adolescent singer, adult musician, and professional educator have led me point out that song teachers either ignore such errors to be identified with. It is therefore recommended that composers make the conscious efforts to record their musical pieces first before it can be recorded by any other choral group or artiste. It is hoped that greater understanding of choral music audio-recording errors, as against the original scores, may initiate further research into issues of copyright which may turn out to be a fundamental driver to check wrong recordings.

\section{REFERENCES}

[1] Acquah, E. O. (2016). Choral Singing and Wellbeing: Findings from a Survey of the Mixed- Chorus Experience from Music Students of the University of Education Winneba, Ghana. Legon Journal of the Humanities, 27(2), 1-13.

[2] Acquah, E.O., Amuah, J.A., Annan, J.F. \& Tsemafo-Arthur (2015). A synchronic study of semantics in selected Akan choral compositions in Ghana. Journal of Music and Dance, 5(4), 16-23.

[3] Amuah, J. A. (2013). A Survey of Choral Art Music Performance Scenes in Ghana. Online International Journal of Arts and Humanities, 2(10), 242-247.

[4] Amuah, J. A., \& Acquah, E. O. (2014). Music analytical presentation of Newlove Annan's mPbD dawur (I will tell it to the world)(Choral composition). International Journal of Asian Social Science, 4(1), 100111.

[5] Amuah, J. A., \& Acquah, E. O. (2013). Twenty Five Years of Choral Music Performance: Contribution of Winneba Youth Choir (WYC) in the Socio-Economic Development of Ghana. Research on Humanities and Social Sciences, 3(19), 105-112.

[6] Benward, B. (2014). Music in Theory and Practice Volume 1. McGraw-Hill Higher Education.

[7] Bernard, H.R. (2002). Research Methods in Anthropology: Qualitative and quantitative methods. (3rd ed.). Alta Mira Press ,Walnut Creek, California.

[8] Burns, A. C., \& Bush, R. F. (2006). Marketing research. Globalization, 1(7).

[9] Ferguson, L (1983). Tape composition: An art form in search of its metaphysics. Journal of Aesthetics and Art Criticisms. 42, 17-27.

[10] Fry, D. B. (1969). The linguistic evidence of speech errors. Brno Studies in English, 8, 69-74.

[11] Garrett, M. F. (1975). The analysis of sentence production. In G. H. Bower (Ed.), The psychology of learning and motivation (pp.133-177). San Diego, CA: Academic Press.

[12] Gundersen, H. J. G., Jensen, E. B. V., Kieu, K., \& Nielsen, J. (1999). The efficiency of systematic sampling in stereology-reconsidered. Journal of microscopy, 193(3), 199-211.

[13] Lewis, J.L. \& Sheppard, S.R.J. (2006). Culture and communication: can landscape visualization improve forest management consultation with indigenous communities? Landscape and Urban Planning, 77, 291313.

[14] Maxfield, J. P. \& Harrison, H.C. (1926). Methods of high-quality recording and reproduction of speech based on telephone research. Bell System Technical Journal, 493-523.

[15] Palmer, C. \&Van de Sande, C. (1993). Units of Knowledge in Music Performance. Journal of Experimental Psychology, 19(2), 457-470.

[16] Randel, D. M. (1978). Harvard Concise Dictionary of Music. USA: Harvard University Press.

[17] Sheldon, D. A. (1998). Effects of contextual sight-singing and aural skills training on error- detection abilities. Journal of Research in Music Education, 46, 384-395. 
[18] Smith, F.J. (1989). Understanding the Musical Experience. Montreux: Gordon and Breach Science Publishers.

\section{AUTHOR'S BIOGRAPHY}

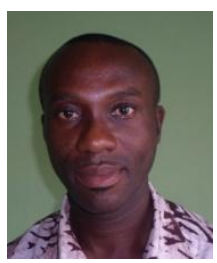

Mr. George Asabre Maclean is a lecturer in the Department of Music Education, University of Education, Winneba, Ghana. He is a scholar in Theory and composition and has much interest researching into issues pertaining to Composition, Choral music Performance and Wind instruments Pedagogies.

Citation: George Asabre Maclean. "An Analytical View of Selected Commercialized Recordings of Ghanaian Art Music Compositions" International Journal of Humanities Social Sciences and Education (IJHSSE), vol 5, no. 2, 2018, pp. 66-75. doi: http://dx.doi.org/10.20431/2349-0381.0502008.

Copyright: (C) 2018 Authors. This is an open-access article distributed under the terms of the Creative Commons Attribution License, which permits unrestricted use, distribution, and reproduction in any medium, provided the original author and source are credited. 